\title{
Why What they Say Matters: The Impacts of Visitors' Experiences on Tourism Sustainability
}

\author{
Adi Suryani ${ }^{*}$, Soedarso ${ }^{2}$, Deti Rahmawati ${ }^{3}$, Endarko $^{4}$, Ahmad Muklason ${ }^{5}$, Berto Mulia \\ Wibawa $^{6}$
}

1,2,3Department of Development Studies, Sepuluh Nopember Institute of Technology, Indonesia

${ }^{4}$ Department of Physics, Sepuluh Nopember Institute of Technology, Indonesia

${ }^{5}$ Department of Information System, Sepuluh Nopember Institute of Technology, Indonesia

${ }^{6}$ Department of Business Management, Sepuluh Nopember Institute of Technology, Indonesia

\section{A R T I C L E I N F O \\ Article history: \\ Received 10 January 2021 \\ Received in revised form \\ 15 January 2021 \\ Accepted 18 February 2021 \\ Available online 25 \\ February 2021}

Keywords:

Visitors' Experience,

Tourism Sustainability

\begin{abstract}
A B S T R A C T
The success and failure of a destination tend to rest on its' capacity to satisfy the visitors. Listening to visitors' appraisal and voices is vital in community-based tourism development. This study aims to explore WPP Dalegan visitors' voices. The data are collected through Dalegan visitors' online reviews and direct observation. The study finds that Dalegan has a high competitive advantage as family recreational destination as it is cheap, reachable, accessible, has various local-traditional-cheap food, beautiful calm beach and soft white sand as a playing and learning ground for children. Despite its' comfortable image, some visitors voice unsatisfied services, facilities, nature-caused and human-caused threats. The study also illuminates that Dalegan destination branding is not only influenced by its' capacity to attract visitors by its' beautiful marine nature, but also local community characters, community education and values. The study indicates that to develop tourism destination, local potentials are not the only determinant keys. It needs to be supported by other determining factors. One of those factors is tourists' voices on their impression, comments, satisfaction and dissatisfaction feelings. Linking potential resources of destination and tourists' meaningful experience can be challenging as different tourists may have different perspectives, wants and satisfaction-dissatisfaction levels.
\end{abstract}

Copyright (C) Universitas Pendidikan Ganesha. All rights reserved.

\section{Introduction}

Indonesia is an archipelago country which is blessed with natural beauty of numerous coastal and marine areas. Almost all areas, from Sumatera to Irian Jaya, particularly those which are near oceans/seas tend to have local marine tourism destinations. Frequently, these local destinations are emerging by coincidence, are found, explored and developed by the local people as a comfortable place for relaxation. The visitors are usually the people around the area, who just want to spend their weekends or short holidays in affordable ways. Many of these destinations are remaining undeveloping, while other destination areas are developing since they are supported by local government and creative local community. These developing destinations can potentially improve local community economic income and reach better life quality, such as improving infrastructure, education, access to external world, increasing sense of pride and becoming more open to change and new experiences.

In spite of their impressive natural beauty, many marine tourism destinations are still ignored, unexplored and intentionally managed. Only some local people who rely their living on the destinations are still caring. They usually sell simple local food and drinks for the local visitors. This social reality of marine tourism condition in Indonesia needs collaboration of government bodies, non-government entities, financial agencies, educational institution, corporate and local community inclusion. The collaborative actions are needed to respond the complexity of marine tourism development. One of development issues faced for developing marine tourism destination is improving the quality of the destination which brings about positive consequences on tourism destination branding. Improved 
positive image may attract more tourists to come across different areas, rather than just from local/surrounding areas. This is because globalization and advancement in transportation allow nondomestic tourists to travel into different destination areas more rapidly and easier, which subsequently increases the tightness of tourism competitiveness (Choi, 2016). More investors and corporate also tend to put their money into promising tourism destination, which may potentially emerge creative changes. Moreover, it is expected that the increasing quantity of tourists' visitation and investments can enhance the local community welfare.

Many previous studies on tourism destination development strongly focus on tourism development based on what the potential natural and social resources destination. However, there are still limited studies focus on exploring or assessing visitors' satisfaction and dissatisfaction as one of several methods to develop tourism destination. As confirmed by Seyfi et al. (2019), studies on tourists' experiences are still in infancy and exist in limited number. Thus, tourism destination development concept is still addressing the potentials of destination resources and neglecting the tourists' experiences. This study contributes to this knowledge gap by linking the local-resources based development to tourist satisfaction and dissatisfaction-based tourism development to create an integrated way to develop community-based tourism. We argue that tourists are not the passive consumers or recipients. Instead, they are one of key stakeholders who determine the sustainability of tourism destination. Happy visitors will come back and feel sense of place attachment (Buonincontri et al., 2017). Without tourists, tourism destination will disappear. Thus, understanding tourists' experiences is vital and need to be regarded as valuable development feedback. As mentioned by Vitters $\varnothing$ et al. (2000), tourist experiences can be information to assess the tourists' satisfaction. Tourists' experiences are keys for tourism attraction development and services quality (Seyfi et al., 2019). Nevertheless, only limited researches are dedicated to explore determinant keys in satisfying tourists (Seyfi et al., 2019). Listening to tourists' voices is increasingly vital today as today's tourists have more sophisticated demands which encourage the tourism destination to improve their tourists' quality experiences (Fernandes \& Cruz, 2016). This need is heightened by the increasing competition in tourism. More tourism destinations emerge lately in Indonesia which demands the tourism managers to explore and satisfy what the tourists' need and want to win the competition. Thus, this study aims to explore tourists' voices and contribute to knowledge gap by suggesting integration of resource-tourism based development and tourists' satisfaction-based development. This means the study links the internal factor and external factors of tourism development.

This study aims to explore WPP (Wisata Pasir Putih/white sand tourism) at Dalegan, Gresik, Jawa Timur. The exploration is focused on potential WPP (branding) improvement analyzed and proposed from WPP tourists perspectives presented in online reviews and the authors' direct visitation to WPP Dalegan. Currently, internet can project and disseminate destination image instantly and world widely. What the tourists say about and impress from their visitation experiences through internet can rapidly viralize or effectively influence others to visit or not visit certain reviewed destination. Thus, word of mouth and online reviews have powerful impacts on destination branding. Different from tourism destination branding studies which are mostly focusing on marketing aspects, this study aims to explore and analyze Dalegan tourists' online reviews after visiting Dalegan as the information to improve WPP-Dalegan destination brand by improving its' tourism service quality and strengthening its' competitive advantages. We argue tourists' voices are strongly impacting tourism sustainability, popularity, branding process and progress. As illuminated by Mikić et al. (2017), quality and authenticity lead to the success of tourism popularity. We propose that service quality improvement impacting on branding and competitive advantage can be achieved by listening to tourists' like, dislike and noting their memorable experiences. During the study, the authors also visit the place to complete the data and see the real situation.

\section{Methods}

The analysis is focused on Dalegan tourists' online evaluation, which are presented in personal blog posting/reviews, instagram and video, travel business web portal. The data selection is focused on visitors' expectation, satisfaction/happiness, dissatisfaction, knowledge/information or critics. The data selection does not cover the promotional information provided by the tourism business owners/executors. Thus, it is restricted to public/community reviews. We believe that nowadays, online reviews can disseminate the evaluation very rapidly and influence other people intention to visit broadly and effectively. As mentioned by Hasan et al (2012), today, online review can substantively form customers' trust. It is also recommended that the tourism destination web provides detail information (Hasan et al., 2012). This is also due to current digital culture, in which people tend to undertake detail analysis before they buy or visit certain destination by googling information, explore the data and learn other people's posting. 
The study adopts a qualitative research paradigm and methods. It intends to capture detail feeling and evaluation of Dalegan visitors. Qualitative method tends to be used to explore people's meaningful knowledge, values and experiences (Byrne, 2012). Qualitative method also tends to listen to informants' view in their own words, which encouraging the implementation of complex analysis (Byrne, 2012). The exploration of Dalegan WPP marine tourism indicates the area specification of the study, which is one of several features of qualitative research. As mentioned by Silverman (2010), qualitative research tends to employ case study and be subjective.

The collected data are analyzed by using thematic analysis and data analysis spiral strategy. The gathered data are analyzed by organizing them into themes, reading the meaningful data, describing and interpreting and representing (Creswell, 2007). The data are also analyzed from within each media to crossing other media to explore data themes. The data analysis and interpretation are also viewed from the perspectives of other existing studies. The emerging themes, discussion and link between findings and existing studies are elaborated into a brand analysis model, which is presented in discussion section. Several pictures taken during the direct observation are presented at the discussion section to provide real situation at WPP-Dalegan.

The data are selected under several criteria. Those are personal/individual public online reviews, which are posted within the latest three years (mid of 2017-mid of 2020) in blog or vlog formats. The study excludes promotional blog or video made by formal institution to attract potential visitors, since we intend to focus on public visitors' real reviews: comments, appraisals, questions and informing.

\section{Results and Discussions}

\section{Results}

The study indicates that developing destination branding associates with understanding visitors' likes and dislikes. What the visitors satisfy or dissatisfy about the destination can trigger management process which improve destination competitiveness. As argued by Sukiman et al. (2013), visitors' satisfaction is the determinant of tourism survival. Moreover, It is necessary to explore attributes leads to customers satisfaction for marketing, promotion, quality increase and customers' loyalty (Yusendra \& Paramitasari, 2018). Dupeyras \& MacCallum (2013) argue that tourists satisfaction is as one of several indicators in measuring destination competitiveness. Moreover, tourism executors/managers need to be aware of the visitors' voices after their visitation (Sukaris et al., 2020).

The collected data are classified on three main clusters. The first data cluster presents Dalegan WPP tourists' satisfaction. The second cluster reveals their dissatisfaction. The third cluster conveys tourists' perceived potential threats and the last data group show some supporting factors. The following table (Table 1) is the first data cluster. It presents several data samples of Dalegan visitors' satisfaction.

Table 1. Tourists' satisfaction

\begin{tabular}{|c|c|c|}
\hline & Statement & $\begin{array}{l}\text { Data meaning } \\
\text { classification }\end{array}$ \\
\hline 1 & $\begin{array}{l}\text { "...its' very beautiful, there are many food sellers...the ticket cheap. There } \\
\text { is a banana boat and the access to the destination is easy" (M1T1-A2) }\end{array}$ & $\begin{array}{l}\text { Many food sellers, } \\
\text { cheap ticket, easy } \\
\text { access }\end{array}$ \\
\hline 2 & $\begin{array}{l}\text { "...great holiday, it is very affordable, yet very exciting for family vacation. } \\
\text { In term of cleanliness, its' very clean, the officers are always ready to } \\
\text { help. Today, there are many visitors come." (M1T1-A4) }\end{array}$ & $\begin{array}{l}\text { Affordable, clean, } \\
\text { ready officers, } \\
\text { suitable for family } \\
\text { recreation }\end{array}$ \\
\hline 3 & $\begin{array}{l}\text { "...white sand at Dalegan Gresik has a big wave, cheap entrance ticket. It's } \\
\text { a very suitable place for family vacation. There are various smoked fish } \\
\text { sold by local people and there is a large parking area." (M1T1-A5) }\end{array}$ & $\begin{array}{l}\text { Cheap price, natural } \\
\text { big wave, suitable for } \\
\text { family recreation, } \\
\text { great and various } \\
\text { local food }\end{array}$ \\
\hline 4 & $\begin{array}{l}\text { "...this destination should one of listed tourism to visit. Besides it has } \\
\text { cheap price, Insya Allah it is comfortable. The coast guard is very active } \\
\text { reminding the visitors to be careful and stay at safe area (M1T1-A6) }\end{array}$ & $\begin{array}{l}\text { Affordable, } \\
\text { comfortable and } \\
\text { active coast guard }\end{array}$ \\
\hline 5 & $\begin{array}{l}\text { "...the wave is very calm and the white sand is very soft and clean. It's } \\
\text { very comfortable to walk on it, even without sandals (but don't walk on it } \\
\text { when the day is very hot). For children under five, the sand is very good } \\
\text { to exercise their motoric system, we don't need to buy kinetic sand..." }\end{array}$ & $\begin{array}{l}\text { Calm wave, soft and } \\
\text { clean white sand, } \\
\text { motoric learning tool } \\
\text { for children under }\end{array}$ \\
\hline
\end{tabular}




Statement

6 "There are many places which rent tire for swimming. The slope is very slight and the wave is not too big, so it is safe for children. Don't come after eight since after eight the place is very hot. There is also boat rent. The boat will take you to the middle of the sea and you can feel the boating sensation." (M1T1-A12)

7 "...the location is not too far from Surabaya city or Gresik, it is just around 1.5-2.5 hours from Manyar-Gresik highway, if there is congestion...at the destination, there are many traditional warung, which sell local cuisine and drink, such as coconut ice, bakso and soto. There is car parking area which is close to the beach. For children under five years, playing ground is provided for them to play trains..." (M1T1-A15)

8 "After ten years I come back, everything has changed. Now many people visit Dalegan. It is more popular. It has many tourism facilities, such as donut tire for swimming, various boats for renting, banana boats, gift market which sells clothes for souvenirs and various smoked fish (M1T1A22)

9 "The main attractive things are its' calm wave and white sand" (M2T1A3)

10 "...there are many exciting activities...the visitors can play white sand, swim, walk around the coast, sit and relax or play kites (M2T2-A4)

11 “...the place is very cool. It's very long time I don't come here." (M5T1-A2)

12 "...it looks like the water makes my skin so itchy. So for others bring your soap from home or buy one around the beach." (M1T1-B1).

13 "...I notice several staff like gangsters. Yesterday, when I deliver a catering for wedding reception at beach, there is a staff who is very rude. If the staff reminds us politely, we will respect. But what he says are very impolite." (M1T1-B18)

14 "one thing which I feel not good is musholla (praying room) should not be charged. I feel it is very funny...I think this is the only place where musholla is being rent. The price is not really expensive, everyone can pay at any price as they like, but I feel that it is too commercial..." (M1T1-B22)

15 "for the toilet...I don't really understand....are the toilets always look like these? Or the toilets cleanliness still can be improved due to this beach increasing popularity and more visitors to come." (M1-T1-B23)

16 "about the facilities, the beach still have limited facilities, compared to other destinations." (M2T1-B5)
Data meaning

classification

five, safe

Various interesting recreational activities, safe for children

Easy access, playing ground for children, various traditional food and drink

$\begin{array}{lr}\text { Better } & \text { tourism } \\ \text { destination, } & \text { more } \\ \text { popular, } & \text { more }\end{array}$ recreational facilities, various souvenirs and smoked fish

Calm wave and soft white sand

Many exciting activities

Improving/getting better destination

Itchy beach water

Dissatisfaction on a staff rude/violent behavior

Dissatisfied with the rented musholla

Dirty toilets

Less facilities

(compared to other destinations)

$\mathrm{M}=$ =media, $\mathrm{T}=$ theme, $\mathrm{A}, \mathrm{B}=\mathrm{a}$ code for a category cluster (each alphabet represents one/certain category)

The data show that not all WPP Dalegan visitors are fascinated. Some of them find that there are several factors which make them less happy. The following table (Table 2), records some dissatisfying aspects.

Table 2. Visitors' dissatisfaction

\begin{tabular}{|c|c|c|}
\hline & Statement & $\begin{array}{l}\text { Data meaning } \\
\text { classification }\end{array}$ \\
\hline 1 & $\begin{array}{l}\text { "...it looks like the water makes my skin so itchy. So for others bring your } \\
\text { soap from home or buy one around the beach." (M1T1-B1). }\end{array}$ & Itchy beach water \\
\hline 2 & $\begin{array}{l}\text { "...but the parking area for cars need to be enlarged. If we can't park the } \\
\text { cars inside, we must park the car outside the available area and it is } \\
\text { expensive." (M1T1-B3) }\end{array}$ & $\begin{array}{l}\text { Limited car parking } \\
\text { area }\end{array}$ \\
\hline 3 & $\begin{array}{l}\text { "...there are still a lot of garbage, maybe it needs more cleaning service } \\
\text { staff...it needs around } 3 \text { hours to reach the destination...I don't know the }\end{array}$ & $\begin{array}{l}\text { Unclean, } \\
\text { number }\end{array}$ \\
\hline
\end{tabular}




\begin{tabular}{|c|c|c|}
\hline & Statement & $\begin{array}{l}\text { Data meaning } \\
\text { classification }\end{array}$ \\
\hline & $\begin{array}{l}\text { closing time. Based on my experience at around 17.30, it should be close, } \\
\text { but I still can take some pictures, is it because there no sufficient staff for } \\
\text { checking the visitors." (M1T1-B17) }\end{array}$ & staff/guard \\
\hline 4 & $\begin{array}{l}\text { "...I notice several staff like gangsters. Yesterday, when I deliver a catering } \\
\text { for wedding reception at beach, there is a staff who is very rude. If the staff } \\
\text { reminds us politely, we will respect. But what he says are very impolite." } \\
\text { (M1T1-B18) }\end{array}$ & $\begin{array}{l}\text { Dissatisfaction on a } \\
\text { staff rude/violent } \\
\text { behavior/gangster } \\
\text { behaviour }\end{array}$ \\
\hline 5 & $\begin{array}{l}\text { "one thing which I feel not good is musholla (praying room) should not be } \\
\text { charged. I feel it is very funny...I think this is the only place where musholla } \\
\text { is being rent. The price is not really expensive, everyone can pay at any } \\
\text { price as they like, but I feel that it is too commercial..." (M1T1-B22) }\end{array}$ & $\begin{array}{l}\text { Dissatisfied with the } \\
\text { rented musholla }\end{array}$ \\
\hline 6 & $\begin{array}{l}\text { "for the toilet...I don't really understand...are the toilets always look like } \\
\text { these? Or the toilets cleanliness still can be improved due to this beach } \\
\text { increasing popularity and more visitors to come." (M1-T1-B23) }\end{array}$ & Dirty toilets \\
\hline
\end{tabular}

The study also finds data relating to tourists' perceived threats and potential threats which may inhibit them to return or encourage them to warn the prospective tourists. The data are classified in third data cluster (Table 3).

Table 3. Several potential threats

\begin{tabular}{|c|c|c|}
\hline & Statement & $\begin{array}{l}\text { Data meaning } \\
\text { classification }\end{array}$ \\
\hline 1 & $\begin{array}{l}\text { "...be careful if you bring children who play around the beach, } \\
\text { sometimes the wave is very high and many people who swim using } \\
\text { swimming tires crash each other..." (M1T1-E2) }\end{array}$ & $\begin{array}{l}\text { High wave-natural } \\
\text { danger }\end{array}$ \\
\hline 2 & $\begin{array}{l}\text { "...actually, Dalegan beach is just ordinary beach, but because there is } \\
\text { no other beach around that area, many people keep on coming..." } \\
\text { (M1T1-E12) }\end{array}$ & $\begin{array}{l}\text { Perceived as ordinary } \\
\text { beach }\end{array}$ \\
\hline 3 & $\begin{array}{l}\text { "...the wave is not really high, like the typical of south beach....but we } \\
\text { should be very careful if we want to swim..." (M1T1-E13) }\end{array}$ & $\begin{array}{l}\text { The hidden risk of calm } \\
\text { wave }\end{array}$ \\
\hline 4 & $\begin{array}{l}\text { "...but when we travel from the main road to the destination, please } \\
\text { be careful, especially if you pass another cars because the road is } \\
\text { narrow." (M1T1-E15) }\end{array}$ & Narrow road \\
\hline 5 & $\begin{array}{l}\text { "I rarely go there, because I usually go there since I was still a little } \\
\text { child, because it is close to my home." (M1T1-E16) }\end{array}$ & $\begin{array}{l}\text { The local people gets } \\
\text { bored }\end{array}$ \\
\hline 6 & $\begin{array}{l}\text { "...from Surabaya, it takes around } 1.5 \text { hours to reach the destination. I } \\
\text { start to go at } 6 \text { and I arrive at WPP at } 7 \text {. The situation is getting hot at } \\
\text { 9. Many people says that if we want to visit WPP, its' better if we come } \\
\text { at } 4 . " \text { (M1T1-E19) }\end{array}$ & $\begin{array}{l}\text { The hot air at certain } \\
\text { time }\end{array}$ \\
\hline 7 & $\begin{array}{l}\text { "...the staff at the entrance way are not friendly...the last time I visit } \\
\text { the place, the tide was low and the there were many garbage..." } \\
\text { (M1T1-E20) }\end{array}$ & $\begin{array}{l}\text { Unfriendly staff, many } \\
\text { garbage }\end{array}$ \\
\hline 8 & $\begin{array}{l}\text { "...at mid-day, the tide is getting high, so be careful if you want to } \\
\text { swim because there are many corals." (M1T1-E24) }\end{array}$ & Many corals \\
\hline 9 & "it has many corals" (M13T1-E5) & Many corals \\
\hline 10 & $\begin{array}{l}\text { "...I notice several staff like gangsters. Yesterday, when I deliver a } \\
\text { catering for wedding reception at beach, there is a staff who is very } \\
\text { rude. If the staff reminds us politely, we will respect. But what he says } \\
\text { are very impolite." (M1T1-B/E18) }\end{array}$ & Gangster tone \\
\hline
\end{tabular}

The fourth data cluster presents several contributing factors. They are structured in Table 4. 
Table 4. Several supporting factors

\begin{tabular}{|c|c|c|}
\hline & Statement & $\begin{array}{l}\text { Data meaning } \\
\text { classification }\end{array}$ \\
\hline 1 & $\begin{array}{l}\text { "Some years ago....this destination is less attractive. So many people didn't } \\
\text { want to come here. The destination is not managed seriously. But now, it } \\
\text { becomes more attractive. Now the destination is managed by Dalegan local } \\
\text { people and it's better now, well treated and looks more amazing" (MS1- } \\
\text { TS8) }\end{array}$ & $\begin{array}{lr}\text { Appreciation } & \text { for } \\
\begin{array}{l}\text { Dalegan } \\
\text { community }\end{array} & \text { local }\end{array}$ \\
\hline 2 & $\begin{array}{l}\text { "there are many local food stands. These can improve local people } \\
\text { economical condition..." (MS1-TS11) }\end{array}$ & $\begin{array}{l}\text { A means for local } \\
\text { community } \\
\text { empowerment }\end{array}$ \\
\hline 3 & $\begin{array}{l}\text { "there are many changes there...its' much better now, very good now. Let's } \\
\text { keep it clean by throwing the garbage at the provided litter bin..." (MS1- } \\
\text { TS16) }\end{array}$ & $\begin{array}{l}\text { Educate others to } \\
\text { keep it clean }\end{array}$ \\
\hline 4 & "It's my village, thank you your coming" (MS4-TS2) & $\begin{array}{l}\text { Appreciating and } \\
\text { feeling of pride }\end{array}$ \\
\hline 5 & $\begin{array}{l}\text { n people feel they are not picnicking if they don't } \\
\text { destination can be an alternative place. Have fun }\end{array}$ & $\begin{array}{l}\text { Going to beach as } \\
\text { part of Indonesian } \\
\text { tourism culture }\end{array}$ \\
\hline 6 & $\begin{array}{l}\text { "May I get the contact number of Dalegan management staff/office? I want } \\
\text { to offer canoe (MS7-TS2) }\end{array}$ & $\begin{array}{l}\text { Increasing } \\
\text { networking }\end{array}$ \\
\hline 7 & $\begin{array}{l}\text { "It's close to my grandmother's house. Every year I always come there" } \\
\text { (MS13-TS9) }\end{array}$ & $\begin{array}{l}\text { Part of annual } \\
\text { culture }\end{array}$ \\
\hline
\end{tabular}

$\mathrm{M}=$ media, $\mathrm{T}=$ theme, $\mathrm{A}, \mathrm{B}=\mathrm{a}$ code for a category cluster (each alphabet represents one/certain category) section).

The description and analysis of each data cluster is presented in the following section (discussion

\section{Discussion}

\section{Destination branding and visitors' satisfaction}

This first subsection of discussion is referring to the first data cluster, as presented in Table (Table 1. Tourists' satisfaction). It aims to examine visitors' satisfaction and potential link to destination branding. The data show that Dalegan visitors satisfy with various aspects of destination. The majority of the visitors find that the destination price is very cheap. This affordability allows the visitors to come with their families and friends in groups. This cheap ticket is reasonable with economic condition of local tourists, as the majority of Dalegan WPP visitors are local people (domestic tourists) who want to spend their leisure time nearby. Risk, expectation, security and price have significant influence on tourists' satisfaction (Aliman et al., 2016).

The other pulling factor is easy access and transportation. Some visitors highlight that to reach the destination is not difficult. This easy access tends to attract people from city around Gresik (such as Surabaya or Jawa Timur) to visit and enjoy natural beach which is not too far from their homes. Distance can affect visitors' intention to revisit and their satisfaction (Som \& Badarneh, 2011). Accessibility and socio-cultural appealing are several satisfying elements determining visitors' revisit intention (Vajčnerová et al., 2014).

The other satisfying factor is the availability of various food at WPP. Several visitors feel satisfy because many local food sellers provide various local/traditional culinary, such as bakso, soto and coconut drink which they can enjoy while they are picnicking. These traditional foods enhance WPP marine tourism by satisfying the eating and drinking needs of visitors. Moreover, they sell culturally tasted cuisines, which are familiar for local visitors. Culture can appeal the visitors (Aunalal et al., 2017), increase the visitors' satisfaction and elevate the souvenir products sales (Filosofova \& Apostolov, 2017) and add the attributes of destination attributes (Zeng, 2017).

Besides the gastro aspects, Dalegan visitors are satisfied with various recreational activities which are suitable for people at any ages, such as swimming, playing on white sand, or just sitting, while eating enjoying food and coast view. The data also reveal a unique recreational activity, such as playing kites, which are exciting traditional leisure activities. Tourists satisfaction is influenced by their motivation and happiness in doing recreational activities (Armario, 2008).

The data also show that several visitors recognize the educational function of white sand, especially for children under five years old. They believe that the sand can help them develop their motoric system. This enhances the popular identity of WPP as family recreational site. Besides the supporting and supplementary attractions, the majority of the visitors come to Dalegan for the main 
attraction, to see the beach which has big but calm wave, which is considered safe by some visitors and the soft and clean white sand which is exciting to play on. The data also demonstrate that the visitors are not only reviewing the natural scenes of WPP, but also the human aspects. They find that the coastal guards are doing their job well by actively always reminding the visitors not to swim into deeper area of beach and the officers are really helpful. Visitors' satisfaction is also influenced by good relationships with the inhabitants, professionals and local government (Gaki et al., 2016). However, the data on human aspect is in contradictory with other data presented in visitors' dissatisfaction which reveal the rude attitude and gangster like behavior of the guards. The data also show the conflicting reviewed situation between the cleanliness of the destination and the dirty toilets. This unclear image conveying conflicting situation between good or bad condition can lead to visitors' dissatisfaction (Corte et al., 2015).

The study demonstrates that to attract WPP Dalegan visitors, several attraction elements need to be provided to support the main attraction. Visitors' satisfaction depends on the interplay of complex process of interdependency of all tourism actors (Corte et al., 2015). It is indicated that accessibility, affordability, gastro aspects, recreational activities variations, staff/guard hospitality/work performance and learning potentials for children are several appealing factors enhancing the beauty of WPP Dalegan and its' white sand. This is relevant to findings of several studies reporting combined elements needed to satisfy visitors. Visitors tend to be satisfied with the provision of interdependent aspects, such as cleanliness, delicious food, natural beauty and artistic aspects (Corte et al., 2015), infrastructure, access, attractions and hospitality, cultural attraction, entertainment, natural beauties and more recreational activities (Khuong \& Nguyen, 2017), reasonable price and quality, local community hospitality, climate, hotel image and availability and leisure activities, price, temperature, attraction, recreational activities (Boit \& Doh, 2014), leisure activities, tourism attractions, service, culture, the behavior of local community, good quality products, security, cleanliness, price, service quality, ranges of facilities and amenities, including food/culinary variations, gift products diversity (Naidoo et al., 2011), accommodation quality, reasonable price, delightful environment, appealing beaches, climate, relevant price, destination experience, local people hospitality, culinary and information (Supitchayangkool, 2012).

The data report that several visitors are saying good things about WPP Dalegan. They promote Dalegan as a comfortable place. Some other visitors revisit the place after several years and excite about WPP progress. All of the above satisfied visitors reveal positive things about WPP and through their reviews, they implicitly recommend others to come. As mentioned by Canny (2013), satisfied tourist tends to say positive information, recommend others to visit and revisit the place. Visitor satisfaction leads to their intention to be loyal (Naidoo et al., 2011) and to revisit (Nugraha, 2019), to enhance the destination image and disseminate good image after visitation (Pereira et al., 2019; Rajesh, 2013). Consistently, visitors' satisfaction increases profits and the success of tourism industries competition. Moreover, customers' satisfaction is an input for devising marketing strategies (do Valle et al., 2006), key for competitive advantage and effective tourism management (Bagri \& Kala, 2015). Thus, management based on visitors' information needs to be employed to increase visitors' satisfaction (Simpson et al., 2020).

\section{Destination branding and visitors' dissatisfaction}

This second part of discussion is referring to the second data cluster. It concerns with tourists' dissatisfaction, as presented in Table 2 (Visitors' dissatisfaction). The data demonstrate that some visitors complain about the quality of beach water, which can be caused by natural or human factors which contaminate or impure the water. Uncleanliness of some toilets and some areas, are which are assumed because of insufficient number of the cleaning service staff, is revealed by some visitors. Other visitors are criticizing the quality of service and the facilities. Lack of tourism infrastructures and quality of amenities can lead to visitors' dissatisfaction (Chavan \& Bhola, 2013; Supitchayangkool, 2012). The rented musholla evokes a visitor's dissatisfaction. The commercialization of musholla is viewed as violating the socialhumanistic value and custom, as praying is the basic spiritual need and obligation. Charging people for praying can be considered as intolerant and too commercial.

The other dissatisfying factor is the behavior of tourism guards/staff. This ignites conflict with the visitors as the visitors feel the guard is impolite and disrespect the visitors and deserving similar rude response/debate. The rude communication of the guard indicates that human capacity/competence aspects can influence visitors perceive value. This is relevant with (Gnanapala, 2015), who argues that employees' inadequate communication skills, road quality and congestion, local vendors attitude, insufficient entertainment \& recreational facilities, discrimination in price and behavior are several impetuous of tourist dissatisfaction. The image of preman (gangster), may project image associated with criminality. This can prohibit others to come. As reported by Corte et al (2015), criminality and unorganized can lead to dissatisfaction. 
The other dissatisfying factor is lack of staff/guards to serve the visitors. This WPP inadequacy is caused by too many visitors who come at holiday session. The crowdedness of visitors can bring about negative consequences, especially if the destination is still lack of human resources, facilities and infrastructures. Maruthaiah \& Rashid (2014) find that crowdedness tends to be perceived differently by the tourists: they can be tolerant or not which subsequently affect their acceptability and satisfaction. This phenomenon emerges dilemmatic situation in tourism development, where either underdevelopment or overdevelopment endangers destination existence and endurance. Thus, it needs further studies focusing on when the tourism development is enough. One of study, executed by Peeters et al (2018), suggest the establishment of policies which are devised collaboratively by government and stakeholders to avoid negative impacts of overtourism. The other dilemmatic challenge is the different perception of each visitor. They may have different level of tolerance, acceptability, satisfaction or dissatisfaction. These differences tend to be influenced by several factors, including visitors' demography, culture, received information and tourists' behavior (Shahrivar, 2012), income and social class (Prayag, 2011).

\section{Potential Threats}

The third data cluster contains tourists' perceived threats. It is presented in Table 3 (several potential threats). The data entail the significance of security and safe feeling of the tourists. The data show that WPP Dalegan visitors are not only expressing their likes and dislikes, but also warning the potential threats to others. Listening and acknowledging their perceived potential risks can improve the quality of service and ensure destination security. As mentioned by Lai et al (2014), personal safety is the most important destination attribute which is expected by visitors from the visited destination. Thus, understanding visitors' perceived threats after their visitation is meaningful to anticipate and alleviate the risks.

The data show that WPP Dalegan visitors remind some potential threats caused by human and nature factors. It is identified that some threats can be managed by improving the service quality, while others risks can only be overcome by mitigating or increasing the visitors' awareness or sensitivity of the potential dangers. Even though usually WPP Dalegan has calm wave, this calmness can unpredictably become deadly wave as it is getting high and endangering children who swim or play around. The high waves are also covering many corals which can endanger visitors who swim. Similarly, WPP Dalegan as possessing similar characteristic to Indonesia south beach, which tends to be calm but dangerous. Thus, the visitor suggests others to keep on being alert, even though the beach frequently looks like very calm. This indicates that Dalegan marine tourism is highly dependent on nature stability. The development of tourism can be inhibited by unfriendly nature (Ronizi et al., 2016). Climate change can substantively influence coastal tourism, even though people know the impacts of changing climate, little concern is devoted for helping people to adapt to changing climate (Fitchett et al., 2016), such as executing adaptive management to reduce, even alleviate tourists discomfort (Mahlangu \& Fitchett, 2009). This is because climate tends to play vital roles in tourism sustainability across the world and failure to adapt can threaten economic sector (Friedrich et al., 2020). Thus, tourism industry needs to improve capacity to adapt to different changes of environment, especially which is supported by government (Calaretu \& Bulin, 2012).

The data indicate that it is not only nature which may pose danger, human behavior can also indicate potential risks. Some WPP Dalegan visitors express their warnings on human-related and infrastructure-related risks, such as narrow road, unfriendly and certain gangster-like staff. Lack of alertness along the narrow road can cause accident, while gangster-climate may pose feeling of anxious and fright which decreases comfortable feeling even secure feeling. As reported by Ghaderi et al (2017), lack of security, high number of crime and unsafe environment can inhibit tourism development. Safety is a significant required condition for tourism development (Kôvári \& Zimányi, 2011).

The study indicates that the sustainability of tourism also rests on its' safe environment. Fuchs \& Pizam (2011) report that safety and security are the primary factors which are considered by visitors in determining their place for vacation. Security is a vital pillar which sustains the destination development as tourists tend to refrain their visit due to insecure image of the destination (Kordić et al., 2015). The ignorance and destination management incapacity to ensure safety can reduce visitors' trust and obstruct tourism sustainability. Insecure destination is less attractive than more secure place. Moreover, safety and security influence visitors' satisfaction and active engagement in recreational activities, destination success and failure, survival capacity and competitiveness (Owiyo \& Mulwa, 2018; Radović \& Arabska, 2016). 


\section{Supporting Factors: community appreciation, education, networking and tourism culture}

The study finds that the electronic word of mouth also demonstrates some other supporting purposes. It is presented in the last data cluster. The data show that the electronic word-of-mouth is not only a means to understand the visitors' perceived satisfaction, dissatisfaction and threats, but also disseminate visitors' positive behavior. This dissemination can effectively enhance destination image and influence other potential visitors to come. The enhanced image is not always associating with the main attraction of WPP Dalegan, but also other dimensions relating to education, culture or psychological dimensions. MS1-TS8, for instance, acknowledges and appreciates the collaborative work of Dalegan local community in initiating and developing WPP Dalegan. This may inspire and motivate other local community who is blessed by beautiful natural environment to creatively initiate and manage their local resources. Recently, many eco-tourisms which is local community-based are flourishing and increasing community welfare. Besides financially benefiting the local community, WPP Dalegan evokes the local residents' sense of pride and appreciation of visitors' coming. This appreciation can evoke the visitors' feeling of being respected and valued. This also shows the exemplary behavior of the residents. Jeuring \& Haartsen (2017) mention that the residents may engage in word of mouth or do supporting behavior triggered by sense of responsibility. The study shows that this sense of responsibility is manifested in appreciating behavior. Electronic word of mouth affects tourists visitation intention after grasping the destination image (Xu et al., 2020), which is intervened by perceived value and quality (Wibowo \& Roostika, 2019).

\section{Triangle Model of Dalegan Marine Development through Destination Branding}

The study finds that what visitors say and disseminate through online reviews potentially influence destination image. The positive word of mouth/review tends to enhance destination image, which may influence potential visitors' perceived value and attractiveness of the destination. Moreover, the credible word of mouth tends to increase brand trust (Wu, 2017).

Dalegan visitors' comments after visitation can also become an input information for the destination management. Their satisfaction can be valuable sources for identifying and positioning Dalegan destination, while some improvements can be executed on the basis of visitors' dissatisfaction after visiting. The study also highlights some potential threats revealed by Dalegan visitors, which can be information for developing WPP Dalegan safety and security systems at individual, group and state levels. Dalegan visitors' satisfaction, dissatisfaction and perceived threats can inform WPP Dalegan competitiveness.

\section{Conclusion}

The study indicates that to develop tourism destination, local potentials are not the only determinant keys. It needs to be supported by other determining factors. One of those factors is tourists' voices on their impression, comments, satisfaction and dissatisfaction feelings. Linking potential resources of destination and tourists' meaningful experience can be challenging as different tourists may have different perspectives, wants and satisfaction-dissatisfaction levels. However, the capacity of tourism destination to find the suitable cutting edge and unique formula of integrating what tourists' wants and potential resources or capacities of tourism destination can bring many positive benefits. It helps the tourism destination to find their unique identity and create strong tourists' attachment which encourages them to return as they have memorable experiences and want to repeat those enjoying memories. This attachment sense can contribute to the tourism sustainability. The study also indicates that developing tourism destination is not only about providing the tourist unforgettable experience, but also providing them safe feeling and ensuring their security. Many existing studies are addressing the attractive dimensions of tourism destination and abandoning security as the most important aspect in tourism. Tourists will not come no matter how attractive the place is, if they feel insecure. The study also finds that tourists' satisfaction is strongly related to tourism branding as the tourists tend to rapidly disseminate their happiness which can increase the tourism popularity or disappointment which inhibits others to come.

\section{References}

Aliman, N. K., Hashim, S. M., Wahid, S. D. M., \& Harudin, S. (2016). Tourists' satisfaction with a destination: An investigation on visitors to langkawi island. British Journal of Marketing Studies, 4(5), 1-20. 
Armario, E. (2008). Tourist satisfaction: An analysis of its antecedents. Universidad, Sociedad y Mercados Globales.

Aunalal, Z. I., Kadir, Abd. R., Taba, Muh. I., \& Hamid, N. (2017). The Influence of Service Quality Dimensions, Destination Image and Satisfaction to Tourist Loyalty in Maluku Province. Scientific Research Journal, V(VI), 71-85.

Bagri, S. C., \& Kala, D. (2015). Tourists' satisfaction at Trijuginarayan, India: An importance-performance analysis. Advances in Hospitality and Tourism Research (AHTR) An International Journal of Akdeniz University Tourism Faculty, 3(2), 89-115.

Boit, J., \& Doh, M. (2014). The role of destination attributes and visitor satisfaction on tourist repeat visit intentions: The case of lake nakuru national park, kenya. Proceeding of the 2014 Northeastern Recreation Research Symposium, 1-9. http://www.esf.edu/nerr/past/.

Buonincontri, P., Marasco, A., \& Ramkissoon, H. (2017). Visitors' Experience, Place Attachment and Sustainable Behaviour at Cultural Heritage Sites: A Conceptual Framework. Sustainability, 9(1112), 1-9. https://doi.org/10.3390/su9071112.

Byrne, B. (2012). Qualitative interviewing. In Researching society and culture (3rd ed., pp. 206-244). SAGE Publication Ltd.

Calaretu, B., \& Bulin, Daniel. (2012). Environmental threats for tourism development. Calitatea, Suppl. Supplement of "Quality - Access to Success" Journal, 13(1), 79-83.

Canny, I. U. (2013). An Empirical Investigation of Service Quality, Tourist Satisfaction and Future Behavioral Intentions among Domestic Local Tourist at Borobudur Temple. International Journal of Trade, Economics and Finance, 4(2), 86-91. https://doi.org/10.7763/IJTEF.2013.V4.265.

Chavan, R., \& Bhola, S. S. (2013). Assessing Tourist Infrastructure of the Satara District: The Views of Visitors. International Journal of Management Research and Business Strategy, 2(3). https://doi.org/10.2139/ssrn.2315633.

Choi, Y. (2016). Exploring factors that affect the destination brand in tourism industry [Master Thesis]. KDI School of Public Policy and Management.

Corte, V. D., Sciarelli, M., Cascella, C., \& Del Gaudio, G. (2015). Customer satisfaction in tourist destination: The case of tourism offers in the city of Naples. Journal of Investment and Management, 4(1-1), 39-50. https://doi.org/10.11648/j.jim.s.2015040101.16.

Creswell, J. W. (2007). Qualitative inquiry \& Research design. Choosing among five approaches (2nd ed.). SAGE Publications Inc.

do Valle, P. O., Silva, J. A., Mendes, J., \& Guerreiro, M. (2006). Tourist Satisfaction and Destination Loyalty intention: A Structural and Categorical Analysis. Int. Journal of Business Science and Applied Management, 1(1), 26-44.

Dupeyras, A., \& MacCallum, N. (2013). Indicators for Measuring Competitiveness in Tourism: A Guidance Document (OECD Tourism Papers 2013/02). OECD Publishing. http://dx.doi.org/10.1787/5k47t9q2t923-en.

Fernandes, T., \& Cruz, M. (2016). Dimensions and outcomes of experience quality in tourism: The case of Port wine cellars. Journal of Retailing and Consumer Services, 31, 371-379.

Filosofova, T., \& Apostolov, D. (2017). Effects of Tourist Satisfaction: Influence on the Touristic Flows (Case Russia-Bulgaria). International Relations. 2017 Current Issues of World Economy and Politics., 285-295.

Fitchett, J. M., Grant, B., \& Hoogendoorn, G. (2016). Climate change threats to two low-lying South African coastal towns: Risks and perceptions. South African Journal of Science, 112(5/6), 1-9.

Friedrich, J., Stahl, J., Hoogendoorn, G., \& Fitchett, JenniferM. (2020). Exploring Climate Change Threats to Beach Tourism Destinations: Application of the Hazard-Activity Pairs Methodology to South Africa. Weather Climate and Society. https://doi.org/10.1175/WCAS-D-19-0133.1.

Fuchs, G., \& Pizam, A. (2011). Importance of Safety and Security for tourism destination. In Destination Marketing and Management. Theories and Applications (pp. 300-313). CAB International. 
Gaki, E., Kostopoulou, S., Parisi, Evangelia. D., \& Lagos, Dimitris. G. (2016). The evaluation of tourism satisfaction in island destinations: The case of the Ionian Islands of Greece. 56th Congress of the European Regional Science Association: “Cities \& Regions: Smart, Sustainable, Inclusive?", 23-26 August 2016, Vienna, Austria. http://hdl.handle.net/10419/174645.

Ghaderi, Z., Saboori, B., \& Khoshkam, M. (2017). Does security matter in tourism demand? Current Issues in Tourism, 20(6), 552-565. https://doi.org/10.1080/13683500.2016.1161603.

Gnanapala, W. K. A. (2015). Tourists Perception and Satisfaction: Implications for Destination Management. American Journal of Marketing Research, 1(1), 7-19.

Hasan, S. A., Subhani, M. I., \& Osman, A. (2012). Effect of Trust Factors on Consumer's Acceptance of Word of Mouth Recommendation. European Journal of Social Science.

Jeuring, J., \& Haartsen, T. (2017). Destination branding by residents: The role of perceived responsibility in positive and negative word-of-mouth. Tourism Planning \& Development, 14(2), 240-259.

Khuong, M. N., \& Nguyen, P. A. (2017). Factors Affecting Tourist Destination Satisfaction and Return Intention - A Study in Ho Chi Minh City, Vietnam. Journal of Economics, Business and Management, 5(2), 95-102. https://doi.org/10.18178/joebm.2017.5.2.493.

Kordić, N., Živković, R., Stanković, J., \& Gajić, J. (2015). Safety and security as factors of tourism destination competitiveness. Key Issues on Tourism Destination Competitiveness. Sitcon. https://doi.org/DOI: 10.15308/sitcon-2015-34-38.

Kôvári, I., \& Zimányi, K. (2011). Safety and security in the age of global tourism (The changing role and conception of Safety and Security in Tourism) (Applied Studies in Agribusiness and Commerce, pp. 59-62) [Scientific Paper]. http://ageconsearch.umn.edu/record/104672/files/10_Kovari_Safety_Apstract.pdf.

Lai, I. K. W., Hitchcock, M., Lu, D., \& Liu, Y. (2014). The Influence of Word of Mouth on Tourism Destination Choice: Tourist-Resident Relationship and Safety Perception among Mainland Chinese Tourists Visiting Macau. Sustainability, 10. https://doi.org/10.3390/su10072114.

Mahlangu, M. M., \& Fitchett, J. M. (2009). Climate change threats to a floral wedding: Threats of shifting phenology to the emerging South African wedding industry. Bulletin of Geography. Socio-Economic Series, 45, 7-23.

Maruthaiah, S., \& Rashid, R. A. (2014). A Review of Visitors Satisfaction and Perception of Crowding. 63-68. http://dx.doi.org/10.15242/ICEHM.ED0314529.

Mikić, A., Bovan, A., \& Jokić, D. (2017). Branding of tourist destination as an important strategic resource of economic development. 9-59.

Naidoo, P., Ramseook-Munhurrun, P., \& Seegoolam, P. (2011). An Assessment of Visitor Satisfaction with Nature-Based T ourism Attractions. International Journal of Management and Marketing Research, $4(1), 87-98$.

Nugraha, K. S. W. (2019). Experiential Marketing: Managing Tourist Satisfaction And Revisit Intention Bangsring Underwater Banyuwangi. International Journal of Scientific \& Technology Research, 8(11), 3475-3479.

Owiyo, V., \& Mulwa, J. M. (2018). Safety and Security in Tourism Destinations: Its moderating role in the Destination Competitiveness Determinants and Destination Competitiveness Nexus in Western Kenya Circuit. International Journal of Research in Management \& Business Studies, 5(3), 30-33.

Peeters, P., Gössling, S., Klijs, J., Milano, C., Novelli, M., Dijkmans, C., Eijgelaar, E., Hartman, S., Heslinga, J., Isaac, R., Mitas, O., Moretti, S., Nawijn, J., Papp, B., \& Postma, A. (2018). Research for TRAN Committee -Overtourism: Impact and possible policy responses (pp. 7-254). European Union. http://www.europarl.europa.eu/thinktank/en/document.html?reference=IPOL_STU(2018)6291 84.

Pereira, L. A., Limberger, P. F., Flores, L. C. da S., \& Pereira, M. de L. (2019). An Empirical Investigation of Destination Branding: The Case of the City of Rio de Janeiro, Brazil. Sustainability, 11(90), 1-17. https://doi.org/10.3390/su11010090. 
Prayag, G. (2011). Paradise for Who? Segmenting Visitors' Satisfaction with Cognitive Image and Predicting Behavioural Loyalty. International Journal of Tourism Research. https://doi.org/10.1002/jtr.

Radović, V., \& Arabska, E. (2016). Why should security aspects be more seriously considered in development of serbian tourism industry? Pregledni Članak, 71-80. https://doi.org/10.5937/timsact10-8127.

Rajesh, R. (2013). Impact of Tourist Perceptions, Destination Image and Tourist Satisfaction on Destination Loyalty: A Conceptual Mode. Revista de Turismo y Patrimonio Cultural, 11(3), 67-78.

Ronizi, S. R. A., Roshan, GH. R., \& Negahban, S. (2016). Assessment of Tourism Climate Opportunities and Threats for Villages Located in the Northern Coasts of Iran. Int. J. Environ. Res, 10(4), 601-612.

Seyfi, S., Hall, C. M., \& Rasoolimanesh, S. M. (2019). Exploring Memorable Cultural Tourism Experiences. Journal of Heritage T Ourism, 1-24. https://doi.org/10.1080/1743873X.2019.1639717.

Shahrivar, R. B. (2012). Factors That Influence Tourist Satisfaction. Journal of Travel and Tourism Research, 61-79.

Silverman, D. (2010). Interpreting qualitative data (3rd ed.). SAGE Publication Ltd.

Simpson, G. D., Patroni, J., Teo, A. C. K., Chan, J. K. L., \& Newsome, D. (2020). Importance-performance analysis to inform visitor management at marine wildlife tourism destinations. Journal of Tourism Futures, 6(2), 165-180.

Som, A. P. M., \& Badarneh, M. B. (2011). Tourist Satisfaction and Repeat Visitation; Toward a New Comprehensive Model. World Academy of Science, Engineering and Technology International Journal of Economics and Management Engineering, 5(2), 239-246.

Sukaris, S., Hartini, S., \& Mardhiyah, D. (2020). The effect of perceived value by the tourists toward electronic word of mouth activity: The moderating role of conspicuous tendency. Jurnal Siasat Bisnis, 24(1), 1-17. https://doi.org/10.20885/jsb.vol24.iss1.art1.

Sukiman, M. F., Omar, S. I., Muhibudin, M., Yussof, I., \& Mohamed, B. (2013). Tourist Satisfaction as the Key to Destination Survival in Pahang. Procedia - Social and Behavioral Sciences, 91, 78-87. https://doi.org/10.1016/j.sbspro.2013.08.404.

Supitchayangkool, S. (2012). The Differences between Satisfied/Dissatisfied Tourists towards Service Quality and Revisiting Pattaya, Thailand. International Journal of Business and Management, 7(6), 30-39.

Vajčnerová, I., Žiaran, P., Ryglová, K., \& Andráško, I. (2014). Quality management of the tourist destination in the context of visitors' satisfaction. Procedia - Social and Behavioral Sciences, 12, 718 - 724. https://doi.org/10.1016/S2212-5671(14)00398-0.

Vittersø, J., Vorkinn, M., Vistad, O. I., \& Vaagland, J. (2000). Tourist Experiences and Attractions. Annals of Tourism Research, 27(2), 432-450. https://doi.org/10.1016/S0160-7383(99)00087-0.

Wibowo, C. P., \& Roostika, R. (2019). Building Positive Word-of-Mouth in the Shopping Tourism. Review of Integrative Business and Economics Research, 8(4), 372-386.

Wu, M. S.-F. (2017). A Study on the Effects of Word-of-Mouth on Brand Trust in Tourism Industry. EURASIA Journal of Mathematics, Science and Technology Education, 13(2), 7995-8002. https://doi.org/10.12973/ejmste/77904.

Xu, F., Niu, W., Li, S., \& Bai, Y. (2020). The Mechanism of Word-of-Mouth for Tourist Destinations in Crisis. SAGE Open, 1-14. https://doi.org/10.1177/2158244020919.

Yusendra, M. A. E., \& Paramitasari, N. (2018). Identifying factors affecting domestic tourist satisfaction on tourist destinations in indonesia. DeReMa Jurnal Manajemen, 13(2), 157-174.

Zeng, B. (2017). Cultural Centre, Destination Cultural Offer and Visitor Satisfaction. Sustainability, 9, 1-12. https://doi.org/doi:10.3390/su9111984. 